\title{
A MODEL OF INFLUENCES OF ENVIRONMENTAL STAKEHOLDERS ON STRATEGIC INFORMATION SYSTEMS PLANNING SUCCESS IN AN ENTERPRISE
}

\author{
Tomaz HOVELJA ${ }^{a}$, Olegas VASILECAS ${ }^{\mathrm{b}}$, Rok RUPNIK ${ }^{c}$ \\ ${ }^{a, c}$ Faculty of Computer and Information Science, University of Ljubljana, \\ Trzaska cesta 25, Ljubljana, Slovenia \\ ${ }^{\mathrm{b} V i l n i u s ~ G e d i m i n a s ~ T e c h n i c a l ~ U n i v e r s i t y, ~ S a u l e t e k i o ~ a l . ~ 11, ~ L T-10223 ~ V i l n i u s, ~ L i t h u a n i a ~}$
}

Received 10 September 2012; accepted 05 November 2012

\begin{abstract}
Worldwide spending of enterprises on information technologies (IT) in 2011 is projected to total USD 2.6 trillion with 350 enterprises each investing more than USD 1 billion. Despite such large and rapidly growing investment figures, the success rates of IT deployment projects over the past 20 years remained relatively low: approximately half of IT deployment projects were unsuccessful. Literature review reveals that inadequate strategic information system planning (SISP) is one of the main reasons for low deployment success rates of IT deployment projects and, thus, one of the current critical IT management issues. For this reason researchers and practitioners in the SISP field are currently directing their efforts into expanding the traditional understanding of SISP as a pure IT planning activity. In addition to the activities dedicated to the planning of IT investments, new SISP models should also include the contextual activities that enable adaptation of the deployed IT to the environment and knowledge transfer from the environment. In this paper, the authors propose an extended SISP model that includes influences of environmental stakeholders. The developed SISP model was empirically tested on a sample from the population of 1000 largest enterprises in Slovenia. The authors believe that the findings of their research and the suggested extended SISP model will improve understanding of SISP success factors in enterprises and consequently enable them to manage their IT investments with greater success.
\end{abstract}

Keywords: strategic information systems planning, IT investments, environmental stakeholders, IT deployment success, enterprises.

Reference to this paper should be made as follows: Hovelja, T.; Vasilecas, O.; Rupnik, R. 2013. A model of influences of environmental stakeholders on strategic information systems planning success in an enterprise, Technological and Economic Development of Economy 19(3): 465-488.

JEL Classification: L20, M10, M15, M20.

Corresponding author Olegas Vasilecas

E-mail: olegas.vasilecas@vgtu.lt 


\section{Introduction}

The current global transformation into the creation and modernization of a sustainable knowledge based society and sustainable knowledge economy is a very complicated process (Melnikas 2010), which among other things requires new information and communication systems for on-line and just-in-time decision-making (Sakalauskas 2010). Consequently, it is not surprising that IT investments in enterprises will soon exceed USD 3 trillion (Gartner 2011). Even more surprising is the fact that the deployment of the most popular IT products in the last two decades (MRP, ERP, CRM, etc.) wasn't able to surpass the standard 25\% to $50 \%$ of the deployment success rates of other less popular IT products (Cooper, Zmud 1990; Brynjolfsson et al. 1997; Umble, E., Umble, M. 2002; Nicho 2004; Arif et al. 2005; Nelson 2007; Mishra, A., Mishra, D. 2011). Strategic information systems planning (SISP) has been widely identified as one of the reasons of low deployment success rates of planned IT investments and, thus, one of the current critical IT management issues (Lederer, Sethi 1988; Hartono et al. 2003; Bechor et al. 2010). Researchers traditionally limited themselves when examining the effect of SISP activities on the success of IT investments to an internal analysis of the enterprise (Lederer, Sethi 1988; Hartono et al. 2003). However, recent findings in the literature (Grover, Sergars 2005; Cohen 2008; Dhillon 2008; Pearlson, Saunders 2009; Bechor et al. 2010) as well as experience of the authors gained during work as consultants for big enterprises in Slovenia allows believing that such internal analysis can ignore important influences of environmental (external) stakeholders on the success of the deployment of IT investments. In line with the established models in the literature on the diffusion of IT innovation (Adler, Shenhar 1990; Fichman 1992; Fowler, Levine 1993; Ramiller, Swanson 1997), the authors understand the environment as a complex system of political, economic, social and cultural conditions affecting an enterprise. Like in literature on the diffusion of IT innovation (DOI), stakeholders are understood as social groups in the environment that have common interests and can influence the way enterprises invest and use information technologies (i.e. owners, competitors, potential competitors, suppliers, customers, IT sellers, IT consultants, governmental institutions and knowledge-forming institutions).

The above-presented issues lead us to definition of SISP as a continuous learning process, encompassing the IS/IT strategy formulation and implementation activities, in which various internal and external (environmental) stakeholders tightly cooperate to assure maximum utilization of IT to achieve sustainable economic success of the enterprise. The majority of other SISP definitions (Lederer, Sethi 1988; Earl 1993) and most popular SISP methodologies (e.g. Business Systems Planning or Information Engineering) usually treat SISP as a process limited to IS/IT strategy formulation and don't include the processes that should be executed during the implementation (e.g. monitoring and evaluation of the progress of implementation, change management etc.). Likewise, they rarely consider the management of the relations with environmental stakeholders as a critical factor of SISP success despite the available empirical papers on the important influences of external environment on the success of the SISP process (Lederer, Salmela 1996; Grover, Segars 2005; Newkirk, Lederer 2006; Cohen 2008; Dhillon 2008; Brown 2008; Pearlson, Saunders 2009; Bechor et al. 2010). Even more problematic may be the fact that external environment remains one of the less 
systematically studied SISP areas with insufficient categorization, integration and superficial examination of some factors (Brown 2008; Cohen 2008; Bechor et al. 2010). To address these problems, the authors will model the SISP process as a broad and complex process that has to address not only the relevant technological issues but also environmental, organizational, behavioural and managerial aspects of IT deployment. Such understanding of the SISP process is grounded in the theory of SISP (Lederer, Salmela 1996), the insights of different versions of Scott-Morton models (Gimenez, Rey 2004) as well as on the IT Interaction Model (Beath et al. 1995) and the above cited DOI literature. The authors hope that the suggested broader SISP model will become a useful tool for IT managers in their efforts to significantly raise the current deployment success rates of IT investments. To achieve this goal and extend the research on the influences of the environment on SISP success, the following research questions need to be addressed:

RQ1. The quality of which key SISP activities affects the success of the SISP process?

RQ2. Are the influences of key environmental stakeholders on the quality of key SISP activities of such importance that their inclusion in a SISP model is reasonable?

RQ3. Does the analysis of the influences of environmental stakeholders on the quality of key SISP activities provide nontrivial information to IT management thus improving the success of IT investments in the enterprise?

RQ4. The quality of which key SISP activities in the enterprise benefits mostly by including different environmental stakeholder groups into the model?

To answer the above-stated research questions, the authors structured the paper as follows. The first section provides a literature review from the relevant fields. Based on it, the authors develop an extended SISP model that includes the influences of environmental stakeholders. The second section presents the methodology used by the authors for research. The third section presents the results of the empirical tests of application of the proposed model in order to answer the research questions presented in this paper. The paper is concluded with the discussion about the main results and possible directions for further research.

\section{Related work}

To achieve the research goal, the authors developed a model that would enable evaluating the entire SISP process from the environmental stakeholders that influence the quality of key SISP activities to the results these SISP activities produce. To thoroughly understand this complex process, the authors reviewed the relevant literature to identify the stakeholders in the environment that influence the quality of key SISP activities. Then, the authors reviewed the literature on key SISP activities to compile the list of those SISP activities whose quality enables an evaluation of the quality of the entire SISP process. The section is finalised with the discussion and identification of IT deployment success variables that the literature considers to be the best. These variables enable an evaluation of the efficiency, with which an enterprise deploys and uses IT, as well as the evaluation of the economic performance of IT investments. Using the identified key variables from the fields of literature presented above, the authors built an extended model of SISP that includes environmental stakeholder influences on SISP success. The model will then be used empirically to evaluate research questions of this paper. 


\subsection{The impact of environmental stakeholders on key SISP activities}

According to the literature, the main problem of an unsuccessful deployment of IT investments by enterprises is the fact that enterprises are generally unable to use a significant part of the implemented IT functionality (Cooper, Zmud 1990; Brynjolfsson et al. 1997; Fichman, Kemerer 1999; Umble, E., Umble, M. 2002; Nicho 2004; Ke, Wei 2008; Ngai et al. 2008; Wang et al. 2008; Trkman, M., Trkman, P. 2009). These long lasting and significant differences between the potential and actual use of IT in enterprises became known as assimilation gaps (Fichman, Kemerer 1999). The literature that studies the diffusion of innovations (DOI) (Loch, Huberman 1999) proposed several models that attempted to explain these assimilation gaps (Adler, Shenhar 1990; Fichman 1992; Fowler, Levine 1993; Ramiller, Swanson 1997; Fichman, Kemerer 1999; Swanson, Wang 2007; Bajec, Vavpotic 2009; Ramiller, Wang 2009; Wang 2010; Hovelja, Vavpotic 2012). These models can be divided into two groups. The first group of models attempts to explain the assimilation gaps through reasons that are purely internal to the enterprises. Reasons given vary highly and range from the time needed by enterprises to learn how to use new technologies and establish appropriate organizational processes for their management to the optional value of IT investments. The optional value of IT investments is the value of a significantly faster achievement of benefits from IT investments if and when these investments start bringing competitive advantages compared to the slower achievement of these benefits in the case that IT investment would only be made after a competitive advantage is identified (Fichman, Kemerer 1999).

The second group of models focuses primarily on the study of the influences of key stakeholder (interest) groups in the environment on the enterprise decisions to invest (buy or develop) and deploy (use) a specific IT product to explain the existence of assimilation gaps. According to these models (Fowler, Levine 1993; Ramiller, Swanson 1997; Swanson, Wang 2007; Kaplinski 2009; Ramiller, Wang 2009; Wang 2010), the interaction of key primary environmental stakeholders (owners, competitors, potential competitors, suppliers, customers) and secondary environmental stakeholders (IT sellers, IT consultants, governmental institutions and knowledge-forming institutions) can create a "must have" vision of specific IT products. This vision, although not necessarily accurate in its evaluation of how important an IT is for an enterprise, significantly influences the IT investments and IT deployment decisions of key internal stakeholders: top management, middle management and IT management. These internal interest groups can thus superficially conform to the environmental stakeholder pressures concerning the "must have" IT by acquiring it even though they never make a serious attempt at using it (Ravichandran et al. 2009). Consequentially, these DOI models see influences of key environmental stakeholder groups as the key environmental forces that impact the success and realization of IT investments through persuasion and knowledge transfer from the environment to the enterprise. The authors understand knowledge transfer as a process between the environment and the enterprise, through which an enterprise is affected by the knowledge and experiences of any environmental stakeholder groups (Holland 1999; Argote, Ingram 2000; Argote et al. 2003).

In contrast to the DOI literature, SISP literature models the external (environmental) influences on the investment and deployment of IT indirectly through their influences on the 
quality of key SISP activities. According to SISP literature, the key SISP activities are namely influenced by three dimensions of the stability of the environment (Lederer, Salmela 1996; Cohen 2008) or environmental uncertainty (King, Sabherwal 1992; King, Teo 1996; Newkirk, Lederer 2006; Bechor et al. 2010). These three dimensions are dynamism, heterogeneity and hostility of the environment (Newkirk, Lederer 2006; Bechor et al. 2010) and affect the rationality, adaptivity, integrativity and communicativeness of the used SISP method (Brown 2008). The authors hope to improve the way the environment is treated and understood in the present SISP models by grounding our SISP model in the DOI.

\subsection{Key SISP activities}

The authors reviewed the relevant literature studying SISP activities in enterprises (Millar, Porter 1985; Davis 1998; Hunger, Wheelen 1998; Appleton 1997; Gottschalk 1999; Ang, Teo 2001; Bresnahan 2001; Chan, Sabherwal 2001; Hedman, Kalling 2001; Kuang et al. 2001; Nelson, Somers 2001; Garg et al. 2002; Hartono et al. 2003; OECD 2004; Palanisamy 2005; Lederer, Newkirk 2006; Bechor et al. 2010) to compile the list of SISP activities that the literature considers crucial for ensuring SISP success (Hovelja et al. 2010). The authors also identified, which stakeholders in enterprises are considered responsible for the successful management of specific SISP activities. These internal stakeholders are the groups of top management, IT management and middle management. The list of the key SISP activities consists of seven SISP planning and seven SISP implementation activities. The seven SISP planning activities are:

- top management commitment and involvement,

- strategic business planning process improvement,

- IT inclusion in strategic business planning,

- alignment of key internal business and IT strategies,

- alignment of key external business and IT strategies,

- management of the consistency of a priority list of IT projects for the realization of internal business strategies,

- management of the consistency of a priority list of IT projects for the realization of external business strategies.

Top management is responsible for the first three activities, while top and IT management share the responsibility for the last four activities.

The seven SISP implementation activities are:

- improvement of the quality of work of project teams,

- the design and implementation of organizational changes,

- the design and implementation of technical and/or technological changes,

- adaptation of the organization/acquired IT to fit the acquired IT/organization,

- involvement of the key user,

- training of the end user in IT use,

- the control and evaluation of the selection, implementation and use of IT. 
The responsibility to manage these activities is shared by top management, IT management and middle management. Middle management should be mainly responsible for improvement of the quality of work of project teams, the involvement of key users and end user training in the use of IT. IT management should be responsible for managing the design and implementation of technical and/or technological changes, while top management should handle the design and implementation of organizational changes, adaptation of the organization/ acquired IT to fit the acquired IT/organization and the control and evaluation of the selection, implementation and use of IT.

\subsection{Evaluation of IT deployment success}

When reviewing the literature on evaluation of IT deployment success, the authors found out they could divide the encountered success variables into two groups. The first group consists of direct measures of IT deployment success that attempt to directly quantify the utilization rate of the deployed IT (Morin, Stevens 2004; Pennoni, Tarantola 2005). On the other hand, the second group of IT deployment success variables attempts to measure the economic performance of IT investments (Dedrick et al. 2003). US Federal Reserve (FED) is generally considered as a leader regarding development of direct IT deployment success measures, specifically the measures of capacity utilization of technology (Morin, Stevens 2004). These measures are used to measure the average rate of efficiency, with which all technologies available to a nation are used (Morin, Stevens 2004). The FED measures the average efficiency (utilization rate of all available technologies) by comparing the current total output of an enterprise to the highest possible output that an enterprise could achieve in the time of a need (war, natural disasters, etc.). Similar measures to specifically estimate the efficiency of IT use in enterprises where employed by the Eurostat (Pennoni, Tarantola 2005). However, instead of asking enterprises about the actual output an enterprise achieves with the available IT, enterprises were asked to estimate the relative output by estimating the percentages of work hours spent using IT.

The second group of IT deployment success variables measure the economic performance of IT investments. These variables were primarily used by researchers that developed different models for measuring the productivity of IT. Among all models, the ones using the added value per employee or the growth of added value per employee as a variable of economic success had the most explaining power (Dedrick et al. 2003).

\section{Proposed extended SISP model}

The proposed extended SISP model is based on the above-presented review of related works. Thus, three main dimensions of the model embody the knowledge of the three reviewed fields of related work: environmental stakeholders, SISP activities and evaluation of IT deployment success.

The environmental stakeholder dimension is represented in the model by key environmental stakeholders (owners, competitors, potential competitors, suppliers, customers, IT sellers, IT consultants, governmental institutions and knowledge-forming institutions). The 
authors, thus, attempt to move beyond the existing three SISP environmental uncertainty dimensions and gain new insights into the relationships between environmental stakeholders and key SISP activities. As the presented DOI literature suggests, the authors also see the interactions of influences of environmental stakeholders as those underlying forces that create the dynamism, heterogeneity and the hostility of an environment. This approach, new to the SISP field, enables an evaluation of the impact of individual environment stakeholders on key SISP activities advancing the analysis of the environment beyond the three standard SISP dimensions of environmental uncertainty. The authors expect that such a move will improve abilities of managers to better understand the influences of each specific environmental stakeholder and consequently manage these influences with greater success. The improvements in understanding and management of these influences will hopefully lead to more successful IT investments, which do not ignore the fact that environmental stakeholder influences are relations that an enterprise can actively manage and not just environmental characteristics to be accepted as given. In the opinion of the authors, such view of the environment by the proposed model offers a significant step forward from the standard view in the literature on SISP that takes the environment as a given bundle of the three dimensions of environmental instability.

The second dimension in the proposed extended SISP model is the SISP activity dimension. This dimension is represented by fourteen activities: seven SISP planning activities and seven SISP implementation activities. The proposed SISP model assumes that the environmental stakeholders from the first dimension importantly influence the quality of these fourteen SISP activities. The model also assumes that the quality, with which these activities are executed in turn affects the success of IT investments.

The third dimension of the proposed SISP model covers the area of evaluation of the success of the deployed IT in an enterprise. In accordance with the review of the related work, the authors measure success through a direct measure of IT utilization as well as through the economic performance of IT investments. To find a direct measure of IT utilization the authors asked the enterprises to estimate the percentage of work hours that are spent using IT and the percentage of work hours that would have to be spent using IT in essential added value producing processes to release the maximum productivity potential of all available IT. These measures for estimation of the efficiency of IT use in enterprises are based on work done by Eurostat and FED. From the second group of variables that measure the economic performance of IT investments, the authors selected added value per employee as the most adequate variable for the proposed SISP model. Literature review namely considers it as the most adequate monetary measure of IT investment performance for research use (Dedrick et al. 2003). In Fig. 1, the authors present a schema of the proposed extended SISP model.

\section{Research methodology}

In this section, the authors address all of the methodological issues that affect the statistical validity and reliability of the results of the empirical test of the proposed SISP model. The authors split these procedural issues into the following three sections: the preparation of the questionnaire, the selection of the appropriate statistical method to conduct the test and the analysis of sample adequacy for parametric testing. 


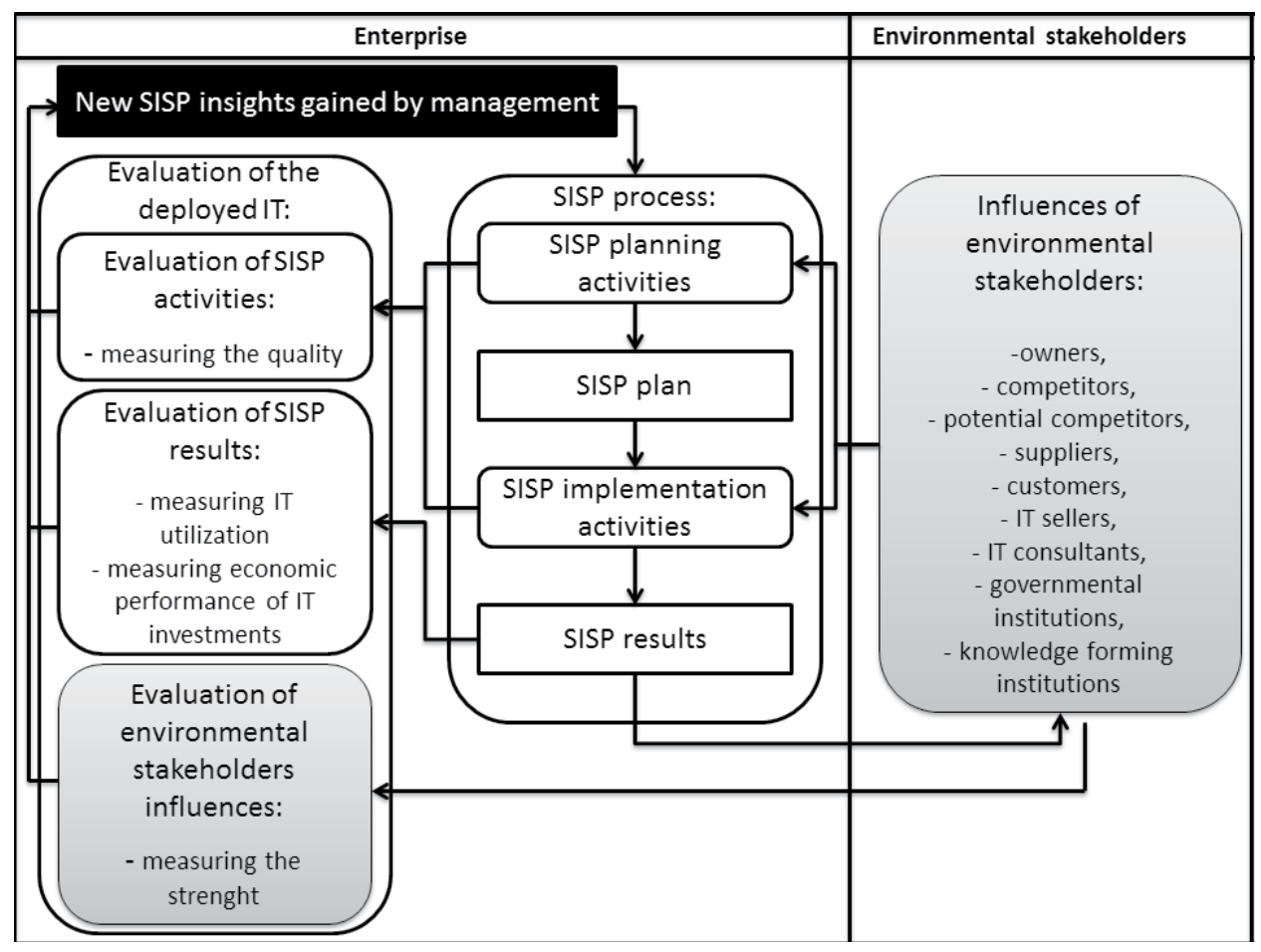

Legend:

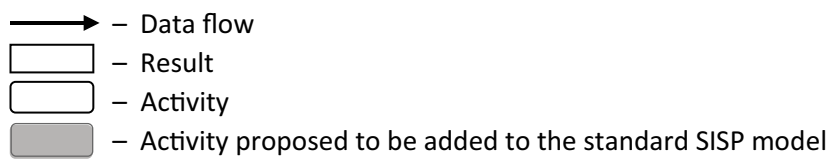

Fig. 1. The extended SISP model

\subsection{The preparation of the questionnaire}

As provided in Fig. 1, the questionnaire had to enable the authors to measure the influence of environmental stakeholders, quality of key SISP activities and SISP results in order to achieve the stated research goals of the paper. The first issue addressed when designing the questionnaire was how to measure the influences of environmental stakeholders on the SISP success and the quality of the key SISP activities that all together form our SISP quality score for an enterprise. The influences of environmental stakeholders on the SISP process were measured with five point Likert scales by asking the respondents to estimate the influences of individual environmental stakeholders identified in the literature review on the SISP process, especially their involvement in enterprise decisions concerning investments and deployments of new IT. The quality of individual SISP activities was similarly measured with five point Likert scales by asking the respondents to estimate the quality of the fourteen individual SISP activities identified in the literature review. 
The authors decided to employ five point Likert scales (strongly agree, agree, neither agree nor disagree, disagree and strongly disagree) because of their conceptual unambiguousness and widespread use. There is also a long established practice of using Likert scales when measuring social phenomena (Newsom 2005), even though Likert scales were considered ordinal by Stevens (1946) and as such inappropriate to be used as interval scales for purposes of computing sample averages and standard deviations. Following Stevens assertions, multiple empirical tests in the social science literature examined his claim and concluded that "for many statistical tests, rather severe departures (from intervalness) do not seem to affect Type I and Type II errors dramatically" (Jaccard, Wan 1996: 4). In addition, there is a large body of literature that on a theoretical level opposes Stevens' view that parametric tests shouldn't be used to test factors measured by any type of ordinal scale. Their view is that as long as the scale has five or more points and the distribution of the measured variable doesn't severely violate the assumptions of normal distribution, one can proceed with parametric testing independent of the type of the measuring scale (Barrett et al. 2005; Newsom 2005). Thus the authors are of the opinion that our results will not be adversely affected in any significant way, if the authors proceed with parametric testing of the employed Likert scales. Since other scales for measurement of IT investments and IT utilization were more in line with the existing literature in these two fields, Likert scales were not used to measure the SISP results dimension of the proposed approach. Two measures of the economic performance of IT investments (added value per employee and growth of added value) didn't have to be measured at all since the authors acquired them directly from the official government-run AJPES database. The relative measures of economic performance were measured by the questionnaire (Growth of Added value in 2004 relative to the industry, to which the enterprise belongs, Growth of Added Value between 2000-2004 relative to the industry to which enterprise belongs) with five point descriptive scales (drastically lower growth then industry, lower growth then industry, the growth of enterprise and industry is equal, higher growth of enterprise then industry, drastically higher growth of the enterprise then industry). IT utilization was also measured by the questionnaire, however after the authors received feedback from the IT managers that helped testing the clarity of the questionnaire, it became clear that its measurement will prove to be a considerable challenge. Several IT managers namely expressed their inability to estimate the initial direct measure of IT utilization that was based on the measure used by US FED: the maximum potential output of all deployed IT.

The IT managers interviewed during the testing of the questionnaire explained how enterprises in Slovenia are not accustomed to use such a measure of IT utilization (US FED based measure: the maximum potential output of the deployed IT), hence they couldn't provide a good estimate of it, since they are not used to think of IT utilization in such way. When asked to provide alternative IT utilization measures they suggested the measurement of planned and actual work hours spent using IT as the best alternative. They explained that because of collective bargaining agreements in Slovenia, the enterprises are used to estimating the planned work hours an end-user spends using IT, since the total planned work hour load of any worker can't be significantly higher than the standard 40 work hours per week. To estimate this number, they ask the sellers of any IT they plan to deploy to provide them the standard/average work hours a trained end-user would have to spend using the newly 
deployed IT in such way as to gain all the benefits from it. If the number of actual work hours spent using IT is significantly higher than the planned number, the IT managers see the difference as a result of end-users taking more time than they should to complete the required »standard«IT enabled tasks. If on the other hand the number of actual work hours spent using IT is significantly lower than the planned number, IT managers see the difference as a result of end-users completing just a part of the planned »standard « IT enabled tasks. Thus, instead of asking about the potential and actual output produced with the support of IT, IT managers were asked to estimate the percentages of work hours that are actually spent using IT and the percentage of work hours that would have to be spent using IT in order to gain all the benefits from the deployed IT. Such measures are closer to the methodology Eurostat employs to measure the use of IT by enterprises (Pennoni, Tarantola 2005), but still based on the empirically confirmed concept that IT creates value through its use in the processes of added value generation (Buonanno et al. 2002; Guimaraes et al. 2002) as defined by Millar and Porter (1985).

\subsection{The analysis of sample adequacy for parametric testing}

The authors collected the needed data for the empirical test of our SISP model between January and May of 2005 and targeted the population of 1000 biggest non-financial enterprises in Slovenia based on the added value they generate. According to official government data, this group generated $40 \%$ of total added value in the country in 2003 and employed $31 \%$ (285.357) of the workforce. To prevent any issues caused by specific differences between the large and small enterprises, we followed the recommendations in the reviewed literature and limited the studied population to enterprises with 25 or more employees. In addition, the authors limited the studied population to enterprises that didn't exhibit larger fluctuations in earnings and employment than $+/-50 \%$ in 2004 . In this way, the authors limited the probability that the observed enterprises didn't have an average business year. After the authors imposed these two limits, the target population of 1000 enterprises diminished to 914 enterprises, which received the questionnaires by mail. 94 appropriately completed questionnaires were received from IT managers.

Based on personal communication and phone communication with the managers of the involved 914 IT departments, the authors concluded that the relatively low $10.28 \%$ response rate was mainly caused by the lack of time and/or knowledge needed to fill out the questionnaire. Redoing the survey with an even more simplified questionnaire would have severely hampered the goals, quality and completeness of our research, thus the authors tried to determine if the 94 "surveyed" enterprises adequately represent the studied population. A sample that is obtained in the above described way is considered adequate for parametric testing when one can assume that the sample's studied variables are not affected by the non-response bias that causes the confidence interval of a sample estimate to not include the actual population value of a studied variable (Fogliani 2002).

Because the variability of the studied variables is the most important cause for a given non-response rate to produce a non-response bias, the authors analysed the sample variability of the economic variables with known population values to find out the amount of 
variability that can be reached, before the sample confidence intervals of their averages stop including the population averages. The Z-tests showed that for the economic variables with known population values, the variability measured by the relative standard deviation in the sample of $110 \%$ or higher caused the $95 \%$ confidence intervals of the sample estimates to not include the actual population values. The only two economic variables that exhibited such large variability were the number of the employees and the created added value per enterprise per year. Since the sample relative standard deviations for studied variables with unavailable population data (SISP activity variables, variables of IT deployment and use) were lower than $65 \%$ of the relative standard deviation, it can be assumed that the economic size bias in the sample, favouring enterprises of larger size, in all probability doesn't statistically significantly affect the variables of interest for this paper. Further tests also showed that the skewness and kurtosis of the studied variables did not exceed the ranges that would greatly violate the assumptions of normality of their distribution which would make parametric testing problematic (Ozgur, Strasser 2004; Barrett et al. 2005).

The reliability of the IT managers responding to the survey was tested with the intra-class correlation coefficient (ICC). Since the authors are developing a method for measuring SISP that will hopefully be used by others, the authors conducted the strictest ICC test, the Two-Way Random Effects model (Ricard 2009), where both raters (IT managers) and items (variables) are viewed as random effects. Because different scores from different IT managers on the 5-point Likert scales can be seen as disagreements, the authors used the Absolute Agreement type model (Ricard 2009). Additionally, the ICC reliability test was based on the average measures ICC, as is standard when the units of analysis are the means of the ratings of the enterprises in the two studied groups (Garson 2009). The average measure of ICC of the dataset was 0.992 . By convention an ICC above 0.7 is considered acceptable and above 0.9 - very good (Garson 2009), thus the authors proceeded with the analysis of the results, under the assumption that the analysed data is sufficiently reliable to be generalised to all possible judges (Garson 2009). The authors also tested the appropriateness of combining the grades of our 14 key success predictors into a single SISP scale using the Cronbach alpha. The widely-accepted social science cut-off point for a set of items to be considered a scale of an alpha of 0.70 or higher (Garson 2010) was surpassed with an alpha score of 0.743 . Based on the results of all the above described tests, the authors can conclude this section by stating that the sample data in all likelihood validly and reliably represents the studied parameters of the targeted population.

\subsection{Method selection}

With all the issues concerning the questionnaire resolved, the authors focused on the process of the selection of the adequate statistical tests to examine the practical usefulness of our SISP method. During this selection process, the authors had a goal to choose a statistical test that would be as robust and simple as possible in order to create a method (IT) managers in enterprises could use independently. Since multivariate tests considerably increase the amount of data (IT) managers would have to collect in order to hold all important influences on the examined variables in the model constant, such tests are not very user-friendly. Consequently, 
our selection process focused on finding the appropriate univariate tests that (IT) managers can conduct without advanced statistical knowledge. The research questions 2, 3 and 4 can thus be answered by conducting Pearson's correlation analysis between the environmental actors and SISP processes. Managers can likewise test the first research question without possessing advanced statistical knowledge by using Student's independent sample t-tests. This test is the standard that is most widely used by the scientific community when one is confronted with several independent interval variables and one ordinal dependent variable (Sharma 1996). Since Student's t-tests analyze only the significance of the difference between the means of two tested groups and not the magnitude of it, the authors additionally calculated for every t-test its Cohen's delta, as the most commonly calculated and cited effect size measures (Brand et al. 2010).

When selecting our ordinal dependent variable, the authors paid special attention to the fact that enterprises have to grasp quickly and firmly the concept behind our statistical testing. Our binomial ordinal variable thus divides the sampled enterprises into two clearly distinguishable groups. The first group is composed of enterprises that achieved $33.3 \%$ of highest SISP quality scores (sums of 14 SISP activities quality scores) in the sample (high SISP quality group). The second group is composed of enterprises that achieved $33.3 \%$ of the lowest SISP quality scores (sum of 14 SISP activities quality scores) in the sample (low SISP quality group). In the opinion of the authors, the statistically significant differences between these two groups clearly, robustly and on a very intuitive level present the key differences between the enterprises that manage SISP with success and the ones that don't.

The decision to use the arbitrary cut of point of one third was made as a compromise between the two conflicting goals of the statistical analysis. The first goal is to clearly confirm that the SISP activity quality scores achieved by enterprises actually correlate with statistically significant differences in the use of IT and economic success of those enterprises. This goal benefits from raising the inclusion point for an enterprise to be selected in the high SISP quality group and lowering the inclusion point for an enterprise to be selected in the low SISP quality group. The greater the difference between the two inclusion points, the greater the difference between the average SISP quality score between the high and low SISP quality groups and the more likely it becomes that the two groups exhibit statistically significant differences in their use of IT and in their economic success. However in contrast with the first goal, the second goal benefits from the inclusion of as many enterprises as possible into the high and low SISP quality groups so that the robustness of the SISP model can be demonstrated. The arbitrary grouping of one third of top and bottom ranked enterprises in each group attempts to fulfill these two conflicting goals as adequately as possible (Hovelja et al. 2010). Such cut of point still presents a very robust number of included enterprises in both groups. However, it also doesn't trivialise the importance of the difference between the SISP scores of enterprises that barely managed to achieve the cut off SISP score for the high SISP or low SISP quality group when the authors express this difference as a percentage of the standard deviation of the sample average SISP quality score. 


\section{Results of the empirical research}

As it can be seen from the Student's t-tests and Cohen d effect sizes in Table 1, the two studied high and low SISP quality groups of enterprises from our sample exhibit statistically significant differences in their average economic success (measured by added value per employee and relative competitive position of the enterprise in the industry) as well as the average success of IT deployment (maximum potential IT use, actual use and IT utilization rate). Such statistically significantly higher averages of SISP results for the group of enterprises with high SISP quality scores are in line with the findings of the reviewed literature and the expectations of our model. The authors can thus answer the research question 1 by stating that the quality of SISP activities, which the authors included in our model, influences the results and thus the success of the SISP process statistically significantly and with moderate to high effect (Cohen d from 0.50 to 0.98 ).

Table 1. Basic descriptive statistics, Independent Student's t-tests and Cohen's d effect sizes between low and high SISP quality groups of enterprises for variables of economic performance of IT investments and variables of the utilization of the deployed IT

Descriptive statistics for:

Independent Student's t-test and Cohen d effect size between Low and High SISP score groups:

\begin{tabular}{|c|c|c|c|c|c|c|c|c|}
\hline \multicolumn{2}{|c|}{$\begin{array}{l}\text { Low SISP quality group }=1, \\
\text { High SISP quality group }=2\end{array}$} & \multirow{2}{*}{$\begin{array}{l}\mathrm{N} \\
33\end{array}$} & \multirow{2}{*}{$\begin{array}{l}\text { Mean } \\
29,639.85 €\end{array}$} & \multirow{2}{*}{$\begin{array}{l}\text { Std. } \\
\text { Deviation } \\
18,959.76 €\end{array}$} & \multirow{2}{*}{$\begin{array}{l}F \\
7.601\end{array}$} & \multirow{2}{*}{$\begin{array}{l}\text { Sig. } \\
0.008\end{array}$} & \multicolumn{2}{|c|}{ Sig. (2-tailed)/Cohen d } \\
\hline $\begin{array}{l}\text { Added Value per } \\
\text { Employee } 2003\end{array}$ & 1 & & & & & & $\begin{array}{l}\text { Equal variances } \\
\text { not assumed }\end{array}$ & 0.049 \\
\hline & 2 & 33 & $43,021.79 €$ & $33,119.18 €$ & & & Cohen d & 0.50 \\
\hline \multirow[t]{2}{*}{$\begin{array}{l}\text { Added Value per } \\
\text { Employee } 2004\end{array}$} & 1 & 33 & $30,929.77 €$ & $18,093.39 €$ & 10.717 & 0.002 & $\begin{array}{l}\text { Equal variances } \\
\text { not assumed }\end{array}$ & 0.028 \\
\hline & 2 & 33 & $47,139.64 €$ & $36,793.82 €$ & & & Cohen d & 0.57 \\
\hline \multirow[t]{2}{*}{$\begin{array}{l}\text { Growth of Added } \\
\text { value in } 2004\end{array}$} & 1 & 33 & $106.52 \%$ & $14.74 \%$ & 0.914 & 0.343 & $\begin{array}{l}\text { Equal variances } \\
\text { assumed }\end{array}$ & 0.439 \\
\hline & 2 & 33 & $109.60 \%$ & $17.26 \%$ & & & Cohen d & 0.19 \\
\hline \multirow{2}{*}{$\begin{array}{l}\text { Growth of Added } \\
\text { value in } 2004 \text { relative } \\
\text { to the industry }\end{array}$} & 1 & 33 & 3.42 & 0.66 & 0.549 & 0.462 & $\begin{array}{l}\text { Equal variances } \\
\text { assumed }\end{array}$ & 0.045 \\
\hline & 2 & 33 & 3.76 & 0.66 & & & Cohen d & 0.52 \\
\hline \multirow{2}{*}{$\begin{array}{l}\text { Growth of Added } \\
\text { Value between } \\
2000-2004 \text { relative } \\
\text { to the industry }\end{array}$} & 1 & 33 & 3.52 & 0.91 & 5.665 & 0.02 & $\begin{array}{l}\text { Equal variances } \\
\text { not assumed }\end{array}$ & 0.13 \\
\hline & 2 & 33 & 3.82 & 0.68 & & & Cohen $\mathrm{d}$ & 0.38 \\
\hline \multirow[t]{2}{*}{$\begin{array}{l}\text { Maximum potential } \\
\text { IT use }\end{array}$} & 1 & 33 & $51.87 \%$ & $21.17 \%$ & 1.528 & 0.221 & $\begin{array}{l}\text { Equal variances } \\
\text { assumed }\end{array}$ & 0.001 \\
\hline & 2 & 33 & $69.49 \%$ & $17.84 \%$ & & & Cohen $\mathrm{d}$ & 0.91 \\
\hline \multirow[t]{2}{*}{ Actual IT use } & 1 & 33 & $39.47 \%$ & $18.60 \%$ & 0.219 & 0.641 & $\begin{array}{l}\text { Equal variances } \\
\text { assumed }\end{array}$ & 0.001 \\
\hline & 2 & 33 & $57.37 \%$ & $18.49 \%$ & & & Cohen d & 0.98 \\
\hline \multirow[t]{2}{*}{ IT utilization rate } & 1 & 33 & $74.97 \%$ & $16.44 \%$ & 1.221 & 0.273 & $\begin{array}{l}\text { Equal variances } \\
\text { assumed }\end{array}$ & 0.049 \\
\hline & 2 & 33 & $82.11 \%$ & $12.13 \%$ & & & Cohen d & 0.50 \\
\hline
\end{tabular}


In Table 2, the authors present the differences between the average positivity of the influences of individual environmental stakeholders on the quality of key SISP activities for the low and high SISP quality groups. Based on the presented differences, the authors can assume that certain environmental stakeholders (owners, competitors, customers, suppliers and IT sellers) statistically significantly and influence the quality of key SISP activities with moderate to high effect size and, thus, their inclusion in the extended SISP model is warranted (RQ2). However, there are some notable exceptions in our empirical test that didn't behave as the literature predicted. The expected statistically significant higher positive influences of potential competitors, IT consultants, governmental and knowledge-forming institutions on the high SISP quality group of enterprises namely can't be empirically confirmed. To establish if the inclusion of these stakeholders in the extended SISP model is justified (RQ2), further analysis will be required. Through such an analysis, the authors will need to find why the empirical results didn't fully conform to the model's predictions that are grounded in theory and empirical studies reported in the literature.

The authors start the above-mentioned analysis by conducting an examination of Pearson's correlations between environmental stakeholders and key SISP quality scores for SISP planning and SISP implementation (Table 3). By separating the overall SISP quality score into the quality of the two key phases of SISP planning and SISP implementation, the authors can additionally answer the third research question that asks whether the model provides nontrivial information for IT managers (RQ3). Such study helps ascertaining that the primary environmental stakeholder groups of owners, competitors, suppliers and customers statistically significantly influence the SISP planning process as well as the SISP implementation process with competitors being the only exception. However, secondary environmental stakeholder groups of IT sellers, IT consultants, governmental and knowledge-forming institutions only statistically significantly influence the quality of the implementation phase but do not influence the quality of planning phase of the SISP process.

Table 2. Basic descriptive statistics, Independent Student's t-test and Cohen d effect size between Low and High SISP score groups for the influences of individual environmental stakeholders on the quality of SISP

\begin{tabular}{|c|c|c|c|c|c|c|c|c|}
\hline \multicolumn{5}{|c|}{ Descriptive statistics for: } & \multicolumn{4}{|c|}{$\begin{array}{l}\text { Independent Student's t-test and Cohen d effect } \\
\text { size between Low and High score SISP groups: }\end{array}$} \\
\hline \multicolumn{2}{|c|}{$\begin{array}{l}\text { Low SISP score group }=1, \\
\text { High SISP score group }=2\end{array}$} & \multirow{2}{*}{$\begin{array}{l}\mathrm{N} \\
33\end{array}$} & \multirow{2}{*}{$\begin{array}{l}\text { Mean } \\
3.15\end{array}$} & \multirow{2}{*}{$\begin{array}{l}\text { Std. } \\
\text { Deviation } \\
1.034\end{array}$} & \multirow{2}{*}{$\begin{array}{l}F \\
0.151\end{array}$} & \multirow{2}{*}{$\begin{array}{l}\text { Sig. } \\
0.699\end{array}$} & \multicolumn{2}{|c|}{ Sig. (2-tailed)/Cohen d } \\
\hline Owners & 1 & & & & & & $\begin{array}{l}\text { Equal variances } \\
\text { assumed }\end{array}$ & 0.007 \\
\hline & 2 & 33 & 3.91 & 1.182 & & & Cohen d & 0.70 \\
\hline \multirow[t]{2}{*}{ Competitors } & 1 & 33 & 3.7 & 1.075 & 1.561 & 0.216 & $\begin{array}{l}\text { Equal variances } \\
\text { assumed }\end{array}$ & 0.029 \\
\hline & 2 & 33 & 4.24 & 0.902 & & & Cohen d & 0.55 \\
\hline \multirow[t]{2}{*}{$\begin{array}{l}\text { Potential } \\
\text { competitors }\end{array}$} & 1 & 33 & 3.91 & 1.071 & 0.001 & 0.991 & $\begin{array}{l}\text { Equal variances } \\
\text { assumed }\end{array}$ & 0.560 \\
\hline & 2 & 33 & 4.06 & 1.029 & & & Cohen $\mathrm{d}$ & 0.15 \\
\hline \multirow[t]{2}{*}{ Suppliers } & 1 & 33 & 2.67 & 1.080 & 0.212 & 0.647 & $\begin{array}{l}\text { Equal variances } \\
\text { assumed }\end{array}$ & 0.005 \\
\hline & 2 & 33 & 3.42 & 1.032 & & & Cohen d & 0.72 \\
\hline
\end{tabular}


Continued Table 2

\begin{tabular}{|c|c|c|c|c|c|c|c|c|}
\hline \multicolumn{5}{|c|}{ Descriptive statistics for: } & \multicolumn{4}{|c|}{$\begin{array}{l}\text { Independent Student's t-test and Cohen d effect } \\
\text { size between Low and High score SISP groups: }\end{array}$} \\
\hline Customers & 1 & 33 & 3.21 & 1.111 & 4.251 & 0.043 & $\begin{array}{l}\text { Equal variances not } \\
\text { assumed }\end{array}$ & 0.002 \\
\hline & 2 & 33 & 4.03 & 0.883 & & & Cohen d & 0.83 \\
\hline \multirow[t]{2}{*}{ IT sellers } & 1 & 33 & 3.21 & 0.960 & 0.036 & 0.85 & $\begin{array}{l}\text { Equal variances } \\
\text { assumed }\end{array}$ & 0.046 \\
\hline & 2 & 33 & 3.67 & 0.854 & & & Cohen d & 0.51 \\
\hline \multirow[t]{2}{*}{ IT consultants } & 1 & 33 & 3.12 & 0.927 & 0.088 & 0.767 & $\begin{array}{l}\text { Equal variances } \\
\text { assumed }\end{array}$ & 0.112 \\
\hline & 2 & 33 & 3.48 & 0.906 & & & Cohen d & 0.40 \\
\hline \multirow[t]{2}{*}{$\begin{array}{l}\text { Knowledge forming } \\
\text { institutions }\end{array}$} & 1 & 33 & 2.55 & 1.121 & 6.119 & 0.016 & $\begin{array}{l}\text { Equal variances not } \\
\text { assumed }\end{array}$ & 0.093 \\
\hline & 2 & 33 & 2.97 & 0.883 & & & Cohen d & 0.42 \\
\hline \multirow[t]{2}{*}{$\begin{array}{l}\text { Governmental } \\
\text { institutions }\end{array}$} & 1 & 33 & 2.39 & 1.088 & 2.344 & 0.131 & $\begin{array}{l}\text { Equal variances } \\
\text { assumed }\end{array}$ & 0.118 \\
\hline & 2 & 33 & 2.79 & 0.927 & & & Cohen d & 0.40 \\
\hline
\end{tabular}

Table 3. Pearson's correlation analysis between environmental factors and key SISP quality scores for SISP planning activities, SISP implementation activities and total SISP activities.

\begin{tabular}{|c|c|c|c|c|c|c|c|c|}
\hline & & \multirow[t]{2}{*}{$\mathrm{N}$} & \multicolumn{2}{|c|}{ SISP planning quality } & \multicolumn{2}{|c|}{$\begin{array}{l}\text { SISP implementation } \\
\text { quality }\end{array}$} & \multicolumn{2}{|c|}{ total SISP quality } \\
\hline & & & $\begin{array}{l}\text { Pearson } \\
\text { Correlation }\end{array}$ & $\begin{array}{l}\text { Sig. } \\
\text { (2-tailed) }\end{array}$ & $\begin{array}{l}\text { Pearson } \\
\text { Correlation }\end{array}$ & $\begin{array}{l}\text { Sig. } \\
\text { (2-tailed) }\end{array}$ & $\begin{array}{l}\text { Pearson } \\
\text { Correlation }\end{array}$ & $\begin{array}{l}\text { Sig. } \\
\text { (2-tailed) }\end{array}$ \\
\hline \multirow{5}{*}{ 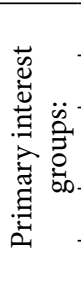 } & Owners & 94 & $0.270^{* *}$ & 0.009 & $0.351^{* *}$ & 0.001 & $0.365^{* *}$ & 0.001 \\
\hline & Competitors & 94 & $0.342^{* *}$ & 0.001 & 0.142 & 0.172 & $0.246^{*}$ & 0.017 \\
\hline & $\begin{array}{l}\text { Potential } \\
\text { Competitors }\end{array}$ & 94 & 0.166 & 0.11 & -0.052 & 0.616 & 0.033 & 0.754 \\
\hline & Suppliers & 94 & $0.259^{*}$ & 0.012 & $0.339^{* *}$ & 0.001 & $0.352^{* *}$ & 0.001 \\
\hline & Customers & 94 & $0.373^{* *}$ & 0.001 & $0.310^{* *}$ & 0.002 & $0.379^{* *}$ & 0.001 \\
\hline \multirow{4}{*}{ 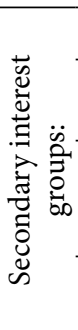 } & IT sellers & 94 & 0.201 & 0.053 & $0.313^{* *}$ & 0.002 & $0.309^{* *}$ & 0.002 \\
\hline & $\begin{array}{l}\text { IT } \\
\text { consultants }\end{array}$ & 94 & 0.073 & 0.486 & $0.291^{* *}$ & 0.004 & $0.239^{*}$ & 0.02 \\
\hline & $\begin{array}{l}\text { Knowledge } \\
\text { forming } \\
\text { institutions }\end{array}$ & 94 & 0.143 & 0.17 & $0.295^{* *}$ & 0.004 & $0.271^{* *}$ & 0.008 \\
\hline & $\begin{array}{l}\text { Governmental } \\
\text { institutions }\end{array}$ & 94 & 0.153 & 0.14 & $0.214^{*}$ & 0.039 & $0.218^{*}$ & 0.035 \\
\hline
\end{tabular}

This inability of secondary environmental stakeholders to influence the planning phase of the SISP process can explain why most of the secondary environmental stakeholder groups (IT consultants, government and knowledge-forming institutions) don't exhibit higher positive influence on the group of enterprises with higher SISP success scores. Conducting SISP planning without secondary environmental stakeholder inputs is typical for the enterprises 
that view SISP planning as a functional activity. Such a view was dominant in the international literature till early nineties; however, especially in the last decade enterprises of the developed West (USA and Western Europe) started considering SISP planning as a strategic activity. The literature, thus, embraced the concept of SISP planning as an activity that needs to be conducted by the top management if an enterprise wants to maximize the indirect benefits brought by IT as a general purpose technology to the enterprise (Mittal, Nault 2006; Basu, Fernald 2007). The adoption of this new concept by an enterprise can symbolically be observed in the promotion of Chief Information Officer (CIO) from a middle management functional position into a strategic top management position.

Thus, the authors can explain the partial differences between the model's predictions grounded in theory and empirical results concerning the empirical test of RQ2 in Table 2 with the fact that even the enterprises with the most sophisticated SISP in Slovenia are lagging behind the enterprises from the developed West in assigning SISP a strategic role instead of a functional one. It seems obvious and unfortunate that the transition process from a socialist economy towards a developed EU economy has not been finished in Slovenia during these 20 years. Thus, it is not surprising that enterprises in Slovenia in general keep CIO positions on a functional level and don't consider them a part of the top management (Erjavec et al. 2010). As a result, the top management in Slovenia lacks the capability to deploy strategies and conduct organizational changes that would be based on new IT products. CIOs as technical IT experts are unable to bridge the process of knowledge and information transfer between the secondary environmental stakeholders and the top management concerning new IT enabled ways to conduct business. Because of their middle management status, CIOs are additionally excluded from most key strategic activities in the enterprise (Levstek, Poljsak 2011).

Judging by empirical evidence from other countries (Mittal, Nault 2006) changing such perceptions would significantly improve the decisions-making process in enterprises during the acquisition, planning and deployment of IT, this way improving the success of IT investments. Since such enterprises - that still regard at least some SISP activities as functional instead of strategic - exist not only in Slovenia and other transitional and developing countries but also in the developed economies of the West, a SISP model that identifies whether an enterprise still conducts a specific SISP activity as a functional activity provides relevant information to the management.

To address the fourth research question (RQ4), about the key SISP activities that benefit mostly by environmental stakeholder inclusion in the SISP process, the authors analyzed the correlations between individual key SISP activities and the positivity of the influences of environmental stakeholders. Table 4 presents the statistically significant correlations that specific key SISP activities have with environmental stakeholders. Based on such analysis, the authors can conclude that several stakeholder groups have a positive statistically significant influence on three key activities of SISP planning These are the top management, commitment and involvement, quality of strategic business planning process and the quality of IT inclusion in strategic business planning. Additionally, several stakeholder groups have a positive statistically significant influence on five key activities of SISP implementation. These are improvements in the quality of work of the project teams, the design and implementation of organizational changes, involvement of key users, end user training for IT use and the control 
and evaluation of the selection, implementation and use of IT. The authors hypothesize that the quality of these activities benefits from environmental stakeholders inclusion in the SISP process through insights gained by management from environmental stakeholders concerning what IT to invest in and how to deploy it (Pearlson, Saunders 2009). Learning from the experiences and knowledge of environmental stakeholders is very beneficial for managers especially when it comes to investments in new IT products. These are usually technically and organisationally complicated to deploy, especially without significant external help. Thus, it is our recommendation for management to develop formal practices that enable the enterprise to efficiently and routinely manage the interests of the environmental stakeholders and in this way gain their knowledge about the type of IT to invest in and they way to deploy these investments (RQ4).

Table 4. Statistically significant correlations between individual environmental stakeholders and key SISP activities

\begin{tabular}{|c|c|c|}
\hline & Key SISP activities: & $\begin{array}{l}\text { Environmental stakeholders that statistically } \\
\text { significantly correlate with a specific SISP activities: }\end{array}$ \\
\hline 1 & $\begin{array}{l}\text { Top management commitment and } \\
\text { involvement }\end{array}$ & $\begin{array}{l}\text { Owners, Competitors, Suppliers, Customers, IT } \\
\text { Sellers }\end{array}$ \\
\hline 2 & $\begin{array}{l}\text { Improvements in strategic business } \\
\text { planning process }\end{array}$ & $\begin{array}{l}\text { Owners, Competitors, Potential Competitors, } \\
\text { Suppliers, Customers, Governmental institutions }\end{array}$ \\
\hline 3 & IT inclusion in strategic business planning & $\begin{array}{l}\text { Competitors, Potential Competitors, Suppliers, } \\
\text { Customers, Governmental institutions }\end{array}$ \\
\hline 4 & $\begin{array}{l}\text { Alignment of key internal business } \\
\text { and IT strategies }\end{array}$ & Knowledge forming institutions \\
\hline 5 & $\begin{array}{l}\text { Alignment of key external business } \\
\text { and IT strategies }\end{array}$ & Governmental institutions \\
\hline 6 & $\begin{array}{l}\text { Managing the consistency of a priority list } \\
\text { of IT projects for the realization of internal } \\
\text { business strategies }\end{array}$ & Competitors, Suppliers \\
\hline 7 & $\begin{array}{l}\text { Managing the consistency of a priority list } \\
\text { of IT projects for the realization of external } \\
\text { business strategies }\end{array}$ & \\
\hline 8 & $\begin{array}{l}\text { Improving the quality of work of the } \\
\text { project teams }\end{array}$ & $\begin{array}{l}\text { Owners, Suppliers, IT sellers, IT consultants, } \\
\text { Governmental institutions }\end{array}$ \\
\hline 9 & $\begin{array}{l}\text { The design and implementation of } \\
\text { organizational changes }\end{array}$ & $\begin{array}{l}\text { Owners, Competitors, Suppliers, Customers, } \\
\text { IT Sellers, }\end{array}$ \\
\hline 10 & $\begin{array}{l}\text { The design and implementation of } \\
\text { technical and/or technological changes }\end{array}$ & Customers, IT Sellers \\
\hline 11 & $\begin{array}{l}\text { Adaptation of the organization/acquired IT } \\
\text { to fit the acquired IT/organization }\end{array}$ & \\
\hline & Involvement of key user & $\begin{array}{l}\text { Owners, Suppliers, Customers, IT Sellers, IT } \\
\text { consultants, Knowledge forming institutions }\end{array}$ \\
\hline & End user training for IT use & $\begin{array}{l}\text { Suppliers, IT Sellers, IT consultants, Knowledge } \\
\text { forming institutions }\end{array}$ \\
\hline & $\begin{array}{l}\text { The control and evaluation of the selection, } \\
\text { implementation and use of IT }\end{array}$ & $\begin{array}{l}\text { Owners, Suppliers, IT consultants, Knowledge } \\
\text { forming institutions, Governmental institutions }\end{array}$ \\
\hline
\end{tabular}


Table 4 additionally provides managers with a clear blueprint about which environmental stakeholders they need to actively involve when conducting a specific SISP activity in order to improve the overall success of the enterprise SISP process. By active involvement the authors understand the establishment of a communication channel, through which management keeps environmental stakeholders aware of what is currently happening in key SISP activities and gathers their knowledge and opinions about how to move forward. Such active involvement, as results of the research indicate, has a positive impact on the overall SISP success of an enterprise by improving and speeding up the feedback the managers receive from the environment, as well as improving the alignment between the enterprise and the environment. Thus, the authors can conclude that the developed model also provides significant nontrivial information to management (RQ3).

The results presented in Table 4 also empirically confirm the importance of all 9 environmental stakeholder influences on the quality of at least some key SISP activities. Based on such results, the authors can thus also answer the second research question (RQ2) that remained partially open and state that all 9 environmental stakeholder influences should be included in a model that evaluates the quality of the SISP process.

\section{Discussion}

The presented empirical tests enable the authors to address all four research questions set at the beginning of this article. Student's t-tests between low and high SISP score groups enable us to test the first research question and answer that the quality of key SISP activities, which the authors identified through literature review, importantly affects the success of the SISP process (RQ1). Statistical testing showed that the quality of SISP activities, which were included by the authors into the developed model had a statistically significant and with moderate to high effect (Cohen d between 0.50 to 0.98 ) influence on the results of the SISP process and, thus, the success of IT investments (see Table 1).

By conducting a Pearson's correlation analysis between environmental factors and key SISP quality scores for SISP planning and SISP implementation (see Table 3), the authors addressed the third research question (RQ3). This research question examines whether nontrivial information for IT managers is gained by analyzing the influences of environmental stakeholders on the quality of key SISP activities. The information is deemed non trivial if it improves the success of IT investments in the enterprise. Based on the statistical testing of the positive impact of environmental stakeholder influences on and involvement in individual SISP activities and overall SISP process success, the authors can conclude that the proposed extended SISP model provides such nontrivial information for IT management.

The fourth research question required the identification of those key SISP activities in the enterprise whose quality is significantly improved by influences of environmental stakeholders. Statistically significant correlations between specific key SISP activities and influences of individual environmental stakeholder groups enabled the authors to also answer this research question (see Table 4). The authors argue that the benefits gained from environmental stakeholder inclusion in the SISP process by the 3 SISP planning and 5 SISP implementation activities that are influenced by several environmental stakeholders are connected with improved learning and knowledge transfer concerning what IT to invest in and how to deploy it. 
The complete analysis needed to answer the above presented research questions (RQ1, RQ3, RQ4) additionally enables the authors to address the second research question (RQ2). This question tackles the issue of sufficient importance of each individual environmental stakeholder influences on the quality of key SISP activities that their inclusion in a SISP model enhances the value of such a model. For five stakeholder groups (owners, competitors, suppliers, customers and IT sellers) whose influences on SISP success are statistically significant with a moderate to strong effect size (see Table 2) the answer "yes" is significantly more straightforward than for the remaining four stakeholder groups (potential competitors, IT consultants, knowledge forming institutions and governmental institutions). However, throughout the analysis of other research questions it became clear that the lack of a positive influence of a certain environmental stakeholder group on the quality of SISP is generally the result of an enterprise's inability or unwillingness to establish appropriate knowledge transfer mechanisms with a specific stakeholder group and not a consequence of the fact that no specific stakeholder group would have relevant knowledge to offer. Thus, the authors think it is reasonable to follow the theoretical models from the analysed literature and include all 9 environmental stakeholder groups in the extended SISP model.

\section{Summary and conclusions}

Despite large and rapidly growing IT investment figures that are approaching USD 3 trillion on the worldwide level, the success rates of IT investment projects remain relatively low. To enable enterprises to improve these low IT investments success rates, the authors developed an extended SISP model, which also includes the influence of environmental stakeholders on SISP activities. The above presented empirical tests of environmental stakeholder influences on the quality and success of SISP activities showed that the developed model provides nontrivial information and improves the understanding of SISP success factors in enterprises. Consequently, it enables managers to manage their IT investments with greater success.

The results of the research strongly support the assumption of the authors that successful management of the SISP process requires active management of the influence of environmental stakeholders. This points to the viability of the proposed model, but certain limitations still need to be addressed. Replication of empirical results was for now namely limited to Slovenia, which as a coordinative market economy considers the interests of several (if not all) primary and secondary stakeholder groups as relevant. Outside of Continental Europe and in countries that are closer to the Anglo-Saxon type of liberal market economy, the influences of owners are usually considered to be substantially more important than the other primary interest groups, while the relevance of secondary interest groups in these countries could be marginal.

Further research thus needs to empirically test the usefulness of the model in different countries, especially in ones with liberal market economies to see if different distribution of power between environmental stakeholders affects the benefits of actively managing their influences in the SISP process. Additional longitudinal qualitative research that would provide in depth examination of the interaction between environmental stakeholders and managers would also be beneficial. Specifically a case study research on exact benefits specific 
environmental stakeholders can offer (knowledge transfer benefits, information transfer benefits, etc.). The authors believe that the findings presented in this paper can serve as a good starting point for such further research as well as provide directions for IT managers in enterprises on how to improve SISP quality and thus manage their IT investments with greater success.

\section{References}

Adler, P.; Shenhar, A. 1990. Adapting your technological base: the organizational challenge, Sloan Management Review 32(1): 25-37.

Ang, J.; Teo, T. 2001. An examination of major IS planning problems, International Journal of Information Management 21(6): 457-470. http://dx.doi.org/10.1016/S0268-4012(01)00036-6

Appleton, E. 1997. How to survive ERP, Datamation 43(3): 50-53.

Argote, L.; Ingram, P. 2000. Knowledge transfer: a basis for competitive advantage in firms, Organizational Behavior and Human Decision Processes 82(1): 150-169. http://dx.doi.org/10.1006/obhd.2000.2893

Argote, L.; McEvily, B.; Reagans, R. 2003. Managing knowledge in organizations: an integrative framework and review of emerging themes, Management Science 49(4): 571-582. http://dx.doi.org/10.1287/mnsc.49.4.571.14424

Arif, M.; Kulonda, D.; Jones, J.; Proctor, M. 2005. Enterprise information systems: technology first or process first?, Business Process Management Journal 11(1): 5-21. http://dx.doi.org/10.1108/14637150510578692

Bajec, M.; Vavpotic, D. 2009. An approach for concurrent evaluation of technical and social aspects of software development methodologies, Information Software Technology 51(2): 528-545. http://dx.doi.org/10.1016/j.infsof.2008.06.001

Barrett, K.; Leech, N.; Morgan, G. 2005. SPSS for intermediate statistics: use and interpretation. Lawrence Erlbaum Associates, London. 240 p.

Basu, S.; Fernald, J. 2007. Information and communications technology as a general-purpose technology: evidence from U.S. industry data, German Economic Review 8(5): 146-173. http://dx.doi.org/10.1111/j.1468-0475.2007.00402.x

Beath, C.; Silver, M.; Markus, L. 1995. The information technology interaction model: a foundation for the MBA core course, Management Information Systems Quarterly 19(3): 361-390. http://dx.doi.org/10.2307/249600

Bechor, T.; Neumann, S.; Zviran, M.; Glezer, C. 2010. A contingency model for estimating success of strategic information systems planning, Information \& Management 47(1): 17-29. http://dx.doi.org/10.1016/j.im.2009.09.004

Melnikas, B. 2010. Sustainable development and creation of the knowledge economy: the new theoretical approach, Technological and Economic Development of Economy 16(3): 516-540. http://dx.doi.org/10.3846/tede.2010.32

Brand, A.; Bradley, M.; Best, L.; Stoica, G. 2010. Multiple trials may yield exaggerated effect size estimates, The Journal of General Psychology 138(1): 1-11. http://dx.doi.org/10.1080/00221309.2010.520360

Brown, I. 2008. Investigating the impact of the external environment on strategic information systems planning: a qualitative inquiry, in Proceedings of the 2008 annual research conference of the South African Institute of Computer Scientists and Information Technologists on IT research in developing countries: riding the wave of technology (SAICSIT 2008), South Africa, George, October 6-8, New York: ACM, 8-15. 
Bresnahan, T. 2001.The mechanisms of information technology's contribution to economic growth [online], [cited 5 November 2002]. Available from Internet: http://www.stanford.edu/ tbres/research/ mechanisms_of_it_contribution.pdf.

Brynjolfsson, E.; Renshaw, A.; Van Alstyne, M. 1997. The matrix of change, Sloan Management Review 38(2): 22-40.

Buonanno, G.; Pigni, F.; Ravarini, A.; Tagliavini, M. 2002. Empirically testing the impact of ICT on business performance within SMEs [online], [cited 5 November 2002]. Available from Internet: http://ticepmi. liuc.it/risorse/store/Empirically_testing_the_impact_of_ICT_on_business_performance_within_ SMEs.pdf.

Chan, Y.; Sabherwal, R. 2001. Alignment betwen business and IS strategies: a study of prospectors, analyzers, defenders, Information Systems Research 12(1): 11-33. http://dx.doi.org/10.1287/isre.12.1.11.9714

Cohen, J. 2008. Contextual determinants and performance implications of information systems strategy planning within South African firms, Information and Management 45(1): 547-555. http://dx.doi.org/10.1016/j.im.2008.09.001

Cooper, R.; Zmud, R. 1990. Information technology implementation research: a technological diffusion approach, Management Science 36(2): 123-139. http://dx.doi.org/10.1287/mnsc.36.2.123

Davis, J.1998. Scooping up vanilla ERP, Infoworld 20(47): 57.

Dedrick, J.; Gurbaxani, V.; Kraemer, K. 2003. Information technology and economic performance: a critical review of the empirical evidence, ACM Computing Surveys (CSUR) 35(1): 1-28. http://dx.doi.org/10.1145/641865.641866

Dhillon, G. 2008. Organizational competence for harnessing IT: a case study, Information and Management 45(5): 297-303. http://dx.doi.org/10.1016/j.im.2008.01.008

Earl, M. 1993. Experiences in strategic information systems planning, MIS Quarterly 17(1): 1-24. http://dx.doi.org/10.2307/249507

Erjavec, J.; Groznik, A.; Gradisar, M.; Indihar-Stemberger, M.; Jaklic, J.; Kovacic, A.; Turk, T.; Popovic, A.; Trkman, P.; Manfreda, A. 2010. Analiza stanja poslovne informatike v slovenskih podjetjih in javnih organizacijah [The analysis of the current state of IT management in Slovenian enterprises and public institutions], Uporabna informatika 18(1): 44-51.

Fichman, R.; Kemerer, C. 1999. The illusory diffusion of innovation: an examination of assimilation gaps, Information Systems Research 10(3): 255-275. http://dx.doi.org/10.1287/isre.10.3.255

Fichman, R. 1992. Information technology diffusion: a review of empirical research, in Proceedings of the Thirteenth International Conference on Information Systems (ICIS), Dallas, USA, December 13-16, Dallas: Association for Information Systems, 195-206.

Fogliani, M. 2002. Low response rates and their effects on survey results. Statistical clearing house [online], [cited 30 September 2002]. Available from Internet: http://www.sch.abs.gov.au/SCH/A1610103. NSF/0/3ce43babf8bbf59dca256b7c0001aea4/pdfFile/0.13FA?OpenElement\&FieldElemFormat=gif.

Fowler, P.; Levine, L. 1993. A conceptual framework for software technology transition. Carnegie Mellon University, Pennsylvania. 27 p.

Garg, A.; Joubert, R.; Pellissier, R. 2002. Review of strategic alignment: its meaning, measurement and impact on business performance, Southern African Business Review 6(1): 38-44.

Garson, D. 2009. Reliability analysis: statnotes from North Carolina State Univesity [online], [cited 15 July 2009]. Available from Internet: http://faculty.chass.ncsu.edu/garson/PA765/reliab.htm.

Garson, D. 2010. Scales and standard measures: statnotes from North Carolina State University [online], [cited 21 August 2010]. Available from Internet: http://faculty.chass.ncsu.edu/garson/PA765/standard.htm\#alpha.

Gartner says worldwide enterprise IT spending to reach \$2.7 trillion in 2012 [online], [cited 2 March 2012]. Gartner Symposium/IT expo 2011, Gartner. Orlando, Fla., October 17, 2011. Available from Internet: http://www.gartner.com/it/page.jsp?id=1824919. 
Gimenez, A.; Rey, C. 2004. Interactions between information technologies and the organization: a conceptual and empirical approach [online], [cited 4 May 2004]. Available from Internet: http://www.ifsam.org/1998/DATA/1.PDF.

Gottschalk, P. 1999. Implementation predictors of strategic information systems plans, Information and Management 36(2): 77-91. http://dx.doi.org/10.1016/S0378-7206(99)00008-7

Grover, V.; Segars, A. 2005. An empirical evaluation of stages of strategic information systems planning: patterns of process, design and effectiveness, Information and Management 42(5): 761-779. http://dx.doi.org/10.1016/j.im.2004.08.002

Guimaraes, T.; Ravarini, A.; Tagliavini, M.; Pigni, F. 2002. Exploring the impact of it on value chain activities and performance of small-medium size companies [online], [cited 5 November 2002]. Available from Internet: http://ticepmi.liuc.it/risorse/store/Exploring_the_Impact_of_IT_on_Value_Chain_Activities_and_Performance_of_Small-Medium_Size_Company.pdf.

Kuang, J.; Lau, J.; Nah, F. 2001. Critical factors for successful implementation of enterprise systems, Business Process Management Journal 7(3): 285-296. http://dx.doi.org/10.1108/14637150110392782

Hartono, E.; Lederer, A.; Sethi, V.; Zhuang, Y. 2003. Key predictors of the implementation of strategic information systems plans, The DATA BASE for Advances in Information Systems 34(3): 41-53. http://dx.doi.org/10.1145/937742.937747

Hedman, J.; Kalling, T. 2001: The business model: a means to understand the business context of information and communication technology [online], [cited 4 January 2002]. Available from Internet: http://www.lri.lu.se/pdf/wp/2001-9.pdf.

Holland, G. 1999. Foreword, in Gray, H. University and the creation of wealth. Buckingham: The Society for Research into Higher Education and Open University Press. 164 p.

Hovelja, T.; Rozanec, A.; Rupnik, R. 2010. Measuring the success of the strategic information systems planning in enterprises in Slovenia, Management: Journal of Contemporary Management Issues 15(2): $25-46$.

Hovelja, T.; Vavpotic, D. 2012. Improving the evaluation of software development methodology adoption and its impact on enterprise performance, Computer Science and Information Systems 9(1): 165-187. http://dx.doi.org/10.2298/CSIS110503072V

Hunger, D.; Wheelen, T. 1998. Strategic management and business policy. New York: Addison Wesley. 344 p.

Jaccard, J.; Wan, C. 1996. LISREL approaches to interaction effects in multiple regression. Thousand Oak: Sage Publications. $112 \mathrm{p}$.

Kaplinski, O. 2009. Information technology in the development of the Polish construction industry, Technological and Economic Development of Economy 15(3): 437-452.

http://dx.doi.org/10.3846/1392-8619.2009.15.437-452

Ke, W.; Wei, K. 2008. Organizational culture and leadership in ERP implementation, Decision Support Systems 45(2): 208-218. http://dx.doi.org/10.1016/j.dss.2007.02.002

King, W.; Sabherwal, R. 1992. The factors affecting strategic information systems applications: an empirical assessment, Information and Management 23(4): 217-235.

http://dx.doi.org/10.1016/0378-7206(92)90046-I

King, W.; Teo, T. 1996. Assessing the impact of integrating business planning and IS planning, Information and Management 30(6): 309-321. http://dx.doi.org/10.1016/S0378-7206(96)01076-2

Lederer, A.; Salmela, H. 1996. Toward a theory of strategic information systems planning, Journal of Strategic Information Systems 5(3): 237-253. http://dx.doi.org/10.1016/S0963-8687(96)80005-9

Lederer, A.; Sethi, V. 1988. The implementation of strategic information systems planning methodologies, MIS Quarterly 12(3): 445-461. http://dx.doi.org/10.2307/249212

Lederer, A.; Newkirk, H. 2006. The effectiveness of strategic information systems planning under environmental uncertainty, Information and Management 43(4): 481-501.

http://dx.doi.org/10.1016/j.im.2005.12.001 
Sakalauskas, L. 2010. Sustainability models and indicators, Technological and Economic Development of Economy 16(4): 567-577. http://dx.doi.org/10.3846/tede.2010.35

Levstek, A.; Poljsak, U. 2011. Analiza razvoja informacijskega sistema v NLB d.d. [Analysis of the NLB information system development], in Zbornik referatov; 17 strokovno posvetovanje o sodobnih vidikih analize poslovanja in organizacije, Portoroz, Slovenija, October 20-21, 2011, Portoroz: Zveza Ekonomistov Slovenija. 88-105.

Loch, C.; Huberman, B. 1999. A punctuated-equilibrium model of technology diffusion, Management Science 45(2): 160-177. http://dx.doi.org/10.1287/mnsc.45.2.160

Millar, V.; Porter, M. 1985. How information gives you competitive advantage, Harvard Business Review 63(4): 149-160.

Mishra, A.; Mishra, D. 2011. ERP project implementation: evidence from the oil and gas sector, Acta Polytechnica Hungarica 8(4): 55-74.

Mittal, N.; Nault, B. 2006. Investments in information technology: indirect effects and information technology intensity [online], [cited 29 March 2006]. Available from Internet: http://papers.ssrn.com/sol3/papers.cfm?abstract_id=909300\#.

Morin, N.; Stevens, J. 2004. Estimating capacity utilization from survey data [online], [cited 5 August 2004]. Available from Internet: http://www.federalreserve.gov/pubs/feds/2004/200449/200449pap.pdf.

Nelson, K.; Somers, T. 2001. Organizations and ERP systems: conceptualizing fit production and operations management society (POMS) [online], [cited 7 September 2002]. Available from Internet: http://www.poms.org/POMSWebsite/Meeting2001/2001/cd/papers/pdf/Somers.pdf.

Nelson, R. 2007. IT project management: infamous failures, classic mistakes, and best practices, MIS Quarterly Executive 6(2): 67-78.

Newkirk, H.; Lederer A. 2006. The effectiveness of strategic information systems planning under environmental uncertainty, Information and Management 43(4): 481-501. http://dx.doi.org/10.1016/j.im.2005.12.001

Newsom, J. 2005. Data analysis I: levels of measurement and choosing the correct statistical test [online], [cited 22 November 2005]. Available from Internet: http://www.ioa.pdx.edu/newsom/da1/ho_levels.doc.

Ngai, E.; Law, C.; Wat, F. 2008. Examining the critical success factors in the adoption of enterprise resource planning, Computers in Industry 59(6): 548-564. http://dx.doi.org/10.1016/j.compind.2007.12.001

Nicho, M. 2004. Implementation failures in customer relationship management software, Applied Computing and Information Technology 2(1).

OECD, The economic impact of ICT; measurements, evidence and implications. Paris: OECD Publishing. 2004. $303 \mathrm{p}$.

Ozgur, C.; Strasser, S. 2004. A study of the statistical inference criteria: can the authors agree on when to use $Z$ versus $t$ ?, The Decision Sciences Journal of Innovative Education 2(2): 177-192. http://dx.doi.org/10.1111/j.1540-4609.2004.00043.x

Palanisamy, R. 2005. Strategic information systems planning model for building flexibility and success, Industrial Management \& Data Systems 105(1): 63-81. http://dx.doi.org/10.1108/02635570510575199

Pearlson, K.; Saunders, C. 2009. Managing and using information systems. $4^{\text {th }}$ edition, Hoboken: Wiley. 400 p.

Pennoni, F.; Tarantola, S. 2005. The European e-business readiness index based on the year 2004 data of 26 countries [online], [cited 14 July 2005]. Available from Internet: http://europa.eu.int/comm/enterprise/ict/policy/ebi/ebi-2004-prelil.pdf.

Ramiller, N.; Swanson, E. 1997. The organizing vision in information systems innovation, Organization Science 8(5): 458-474. http://dx.doi.org/10.1287/orsc.8.5.458

Ramiller, N.; Wang, P. 2009. Community learning in information technology innovation, MIS Quarterly 33(4): 709-734. 
Ravichandran, T.; Shu, H.; Hasan, I. 2009. Effects of institutional pressures on information technology investments: an empirical investigation, IEEE Transactions on Engineering Management 56(4): 677-691. http://dx.doi.org/10.1109/TEM.2009.2032037

Ricard, M. 2009. Test-retest reliability and standard error of measurement [online], [cited 24 July 2009]. Available from Internet: http://www.powmri.edu.au/fbrg/iccs.pdf.

Sharma, S. 1996. Applied multivariate techniques. New York: John Wiley and Sons. 493 p.

Stevens, S. 1946. On the theory of scales of measurement, Science 103(2684): 677-680. http://dx.doi.org/10.1126/science.103.2684.677

Swanson, B.; Wang, P. 2007. Launching professional services automation: institutional entrepreneurship for information technology innovations, Information and Organization 17(2): 59-88. http://dx.doi.org/10.1016/j.infoandorg.2007.02.001

Trkman, M.; Trkman, P. 2009. A wiki as intranet: a critical analysis using the Delone and McLean model, Online information review 33(6): 1087-1102. http://dx.doi.org/10.1108/14684520911011025

Umble, E.; Umble, M. 2002. Avoiding ERP implementation failure, Industrial Management 44(1): 25-33.

Wang, E.; Shih, S.; Jiang, J.; Klein, G. 2008. The consistency among facilitating factors and ERP implementation success: a holistic view of fit, Journal of Systems and Software 81(9): 1609-1621. http://dx.doi.org/10.1016/j.jss.2007.11.722

Wang, P. 2010. Chasing the hottest IT: effects of information technology fashion on organisations, MIS Quarterly 34(1): 63-85.

Tomaž HOVELJA. He received his Bachelor's degree, Master's degree and his PhD in Business Administration from the Economic Faculty at the University of Ljubljana. He is employed as an assistant at the Faculty of Computer and Information Science at the University of Ljubljana. His research has appeared in journals such as Journal of Systems and Software, Computer Science and Information Systems, Economic and Business Review for Central, South-Eastern Europe. His research interests include social, economic and organizational factors of IT deployment in enterprises and IT project success criteria.

Olegas VASILECAS. He is a full time professor at the Information Systems Department, and principal researcher and head of Information Systems Research Laboratory in Vilnius Gediminas Technical University. He is author and co-author of more than 250 research papers and 5 books in the field of information systems development. He delivered lectures in 7 European universities including London, Barcelona, Athens and Ljubljana. Vasilecas carried out an apprenticeship in Germany, Holland, China, and last time in Latvia and Slovenia universities. He supervised 10 successfully defended doctoral theses and now is supervising 4 more doctoral students. He was a leader of number of international and local projects. Last time he headed "Business Rules Solutions for Information Systems Development (VeTIS)" project carried out under High Technology Development Program of Lithuania. His research interests include knowledge, represented by business rule and ontology, information systems development.

Rok RUPNIK. He received his Bachelor's degree, Master's degree and his PhD in Computer science from the Faculty of Computer and Information Science at University of Ljubljana. He is assistant professor at Faculty of Computer and Information Science at University of Ljubljana. From October 2012, he is also the product manager for mobile applications at Datalab company. He published several papers in SCI and SSCI journals. In 2009, he received PMP (project management professional) certificate issued by PMI (Project management institute). His research interests include project management, information systems development methodologies, information systems strategic planning, decision support systems and mobile applications. 